\title{
WATERMELON STOMACH: clinical aspects and treatment with argon plasma coagulation
}

\author{
Dalton M. CHAVES ${ }^{1}$, Paulo SAKAI ${ }^{1}$, Cláudio V. OLIVEIRA ${ }^{2}$, \\ Spencer CHENG $^{1}$ and Shinichi ISHIOKA ${ }^{1}$
}

\begin{abstract}
Background - Gastric antral vascular ectasia is a disorder whose pathogenetic mechanism is unknown. The endoscopic treatment with argon plasma coagulation has been considered one of the best endoscopic therapeutic options. Aim - To analyze the endoscopic and clinical features of gastric antral vascular ectasia and its response to the argon plasma coagulation treatment. Patients and Methods - Eighteen patients were studied and classified into two groups: group 1 - whose endoscopic aspect was striped (watermelon) or of the diffuse confluent type; group 2 - diffuse spotty nonconfluent endoscopic aspect. Results - Group 1 with eight patients, all having autoimmune antibodies, but one, whose antibodies were not searched for. Three were cirrhotic and three had hypothyroidism. All had gastric mucosa atrophy. In group 2, with 10 patients, all had non-immune liver disease, with platelet levels below 90.000. Ten patients were submitted to argon plasma coagulation treatment, with 2 to 36 months of follow-up. Lesions recurred in all patients who remained in the follow-up program and one did not respond to treatment for acute bleeding control. Conclusion - There seem to be two distinct groups of patients with gastric antral vascular ectasia: one related to immunologic disorders and other to non-immune chronic liver disease and low platelets. The endoscopic treatment using argon plasma coagulation had a high recurrence in the long-term evaluation.
\end{abstract}

HEADINGS - Gastric antral vascular ectasia. Gastrointestinal hemorrhage. Electrocoagulation.

\section{INTRODUCTION}

Gastric antral vascular ectasia (GAVE) was first recognized by RIDER et al. ${ }^{(18)}$, in 1953, although only in 1984, JABBARI et al. ${ }^{(10)}$ called it "watermelon stomach" as it became known, relating its striped aspect to a watermelon peel.

Upper digestive endoscopy is important not only for the diagnosis, but also in treatment, because most patients have high surgical risk due to the severity of other diseases.

GAVE is sometimes confused with hemorrhagic gastritis or portal hypertensive gastropathy specially, if the endoscopist is not familiar with the aspect of the lesion. Diagnosis is based on the clinical history, endoscopic appearance and histologic findings of vascular ectasia with fibrin clots and fibromuscular hyperplasia of the lamina propria ${ }^{(10,20)}$.

This study reports the experience of the Endoscopy Service of "Hospital das Clínicas", University of São Paulo Medical School (HC-FMUSP), São Paulo, SP,
Brazil, diagnosing and treating 18 patients with GAVE, where treatment with argon plasma coagulation (APC) was adopted in most of the cases.

\section{PATIENTS AND METHODS}

Eighteen patients with GAVE were evaluated in the Endoscopy Service of HC-FMUSP.

Once GAVE was diagnosed, laboratorial tests were performed to evaluate hepatic, renal and thyroid function, complete blood count, coagulation tests, antimitochondrial and smooth muscle antibodies, and in the last two patients antiparietal cell antibody was also tested. Routine gastric antral and body biopsies were taken from the stomach and associated lesions. All patients had histological confirmation of the diagnosis.

The first patient was submitted to surgical treatment because APC was not available at the time. After acquiring the equipment, its use was the preferred form of treatment, regulated at $60 \mathrm{~W}$ power and 2 liters/minute flow.

\footnotetext{
${ }^{1}$ Endoscopy Service, University of São Paulo Medical School, São Paulo, SP, Brazil; ${ }^{2}$ Endoscopy Service, Federal University of Bahia School of Medicine, Salvador, BA, Brazil. Address for correspondence: Dr. Dalton Marques Chaves - Rua Montezuma, 183 - 05436080 - São Paulo, SP, Brazil. E-mail: dalton.chaves@fleury.com.br
} 


\section{RESULTS}

Of 18 evaluated patients $12(68.75 \%)$ were women and 6 $(31.25 \%)$ were men. Two were black and 16 were white, age range from 38 to 71 years (median 54.7).

Analyzing clinical and endoscopic features we observe two different groups of patients: group I - patients with a striped form of endoscopic presentation (watermelon stomach) or a homogeneous pattern leading to a diffuse antral redness, associated with gastric mucosa atrophy, mainly represented by autoimmune diseases patients with autoantibodies; group II - liver disease and trombocytopenic patients, endoscopically characterized by small, isolated, red dots, widespread in the antral mucosa (Figure 1).

Group I, with eight patients, in three GAVE was of the watermelon type and five had diffuse redness. All patients had gastric mucosa atrophy. Regarding gender, three were males and five were females, with age ranging from 50 to 74 years (average 61.3). One to 12 months of anemia history, hemoglobin levels ranged from 4.5 to 10.0 $\mathrm{g} / \mathrm{dL}$ (average 6.9), prothrombin activity of $50 \%$ to $97 \%$ (average $79.3 \%$ ), international normalized ratio (INR) 1.03 to 1.84 (average 1.42), and platelet count 156 to $277 \times 10^{3} / \mathrm{mm}^{3}$ (average $237.25 \times$ $10^{3} / \mathrm{mm}^{3}$ ). Group II, with 10 patients, without evident gastric mucosa atrophy, 3 males and 7 females, age ranging from 38 to 71 years (average 49.3), 1 to 24 months of anemia history, hemoglobin levels 4.8 to $11.2 \mathrm{~g} / \mathrm{dL}$ (average 8.0 ), prothrombin activity $30 \%$ to $70 \%$ (average 52\%), INR 1.18 to 1.69 (average 1.60), and platelets 29 to $90 \times 10^{3} / \mathrm{mm}^{3}$ (average $55.4 \times 10^{3} / \mathrm{mm}^{3}$ ) (Table1).

Regarding the association with others diseases, in group I there were three patients with hepatic cirrhosis (one primary biliary cirrhosis, two cryptogenic), and one patient with cryptogenic cirrhosis had also antiparietal cell antibodies with titers above
1/320. One patient presented antimitochondrial antibodies with titers above $1 / 80$, but hepatic disease was not confirmed despite hepatic biopsies. Another patient, with normal hepatic function, presented antiparietal cell antibody above $1 / 40$. Hypothyroidism was diagnosed in three other patients, with antithyroglobulinpositive antibodies. Other observed illnesses were coronary disease (one patient), type II diabetes (two patients), high blood pressure (two patients), chronic renal failure (one patient) and

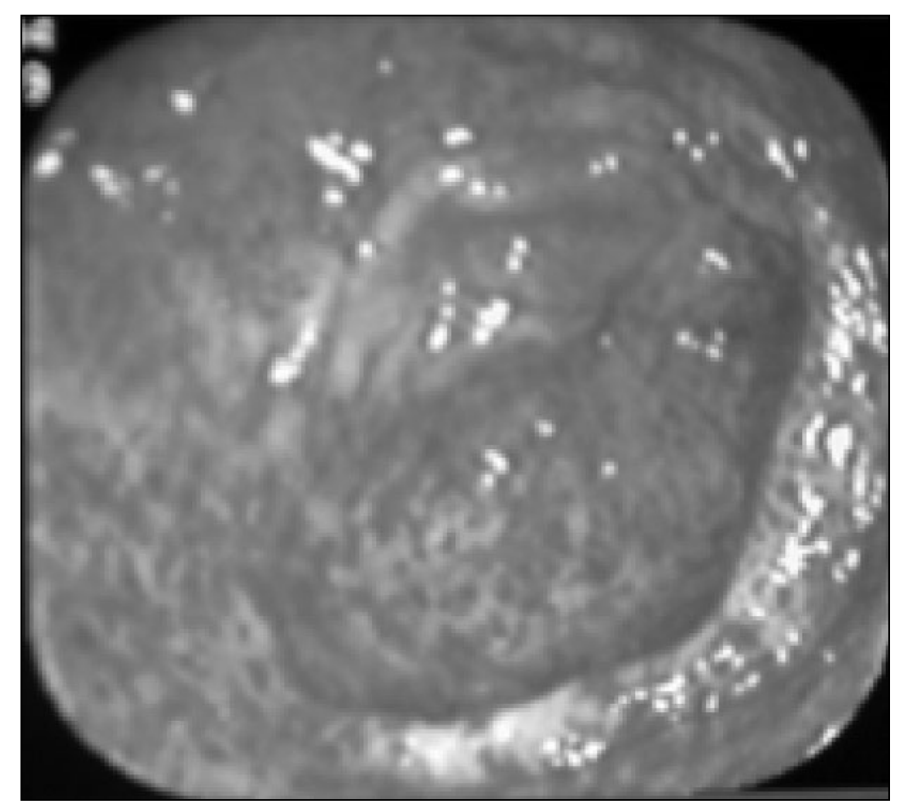

FIGURE 1 - GAVE, spotty type, with small dots of vascular ectasia, widespread in the antrum

TABLE 1 - Clinical findings

\begin{tabular}{|c|c|c|c|c|c|c|c|}
\hline \multicolumn{8}{|c|}{ Group I } \\
\hline Pat. & Gender & Age & Anemia(months) & $\mathbf{H b}$ & Platelets (g\%) & PT & INR (\%) \\
\hline 1 & $\mathrm{M}$ & 71 & 3 & 4.5 & 165000 & 50 & 1.6 \\
\hline 2 & $\mathrm{M}$ & 52 & 1 & 6 & 189000 & 80 & 1.09 \\
\hline 3 & $\mathrm{~F}$ & 74 & 12 & 8 & 190000 & 97 & 1.84 \\
\hline 5 & F & 50 & 12 & 6 & 277000 & 96 & 1.82 \\
\hline 7 & $\mathrm{~F}$ & 57 & 3 & 6 & 156000 & 79 & 1.11 \\
\hline 10 & $\mathrm{~F}$ & 63 & 12 & 10. & 176000 & 85 & 1.03 \\
\hline 15 & $\mathrm{~F}$ & 55 & 5 & 5.8 & 264000 & 52 & 1.73 \\
\hline 18 & $\mathrm{M}$ & 69 & 12 & 9,0 & 305000 & 96 & 1.14 \\
\hline \multicolumn{8}{|c|}{ Group II } \\
\hline 4 & $\mathrm{~F}$ & 47 & 2 & 4.8 & 61000 & 57 & 1.41 \\
\hline 6 & F & 71 & 4 & 5 & 65000 & 70 & 1.18 \\
\hline 8 & $\mathrm{~F}$ & 57 & 1 & 9.5 & 50000 & 57 & 1.44 \\
\hline 9 & $\mathrm{~F}$ & 50 & 1 & 5.9 & 75000 & 57 & 1.44 \\
\hline 11 & M & 67 & 1 & 8.1 & 90000 & 47 & 1.69 \\
\hline 12 & $\mathrm{M}$ & 46 & 1 & 11.2 & 45000 & 30 & 2.52 \\
\hline 13 & $\mathrm{~F}$ & 38 & 3 & 8.6 & 45000 & 61 & 1.4 \\
\hline 14 & $\mathrm{~F}$ & 39 & 6 & 8.7 & 29000 & 49 & 1.9 \\
\hline 16 & $\mathrm{M}$ & 39 & 24 & 8.5 & 44000 & 40 & 1.6 \\
\hline 17 & $\mathrm{~F}$ & 39 & 5 & 10 & 50000 & 52 & 1.44 \\
\hline
\end{tabular}

$\mathrm{Hb}=$ hemoglobin

$\mathrm{Hb}=$ hemoglobin
$\mathrm{PT}=$ prothrombin time 
Raynaud's phenomenon (one patient). In group II, there was an association with chronic hepatic disease in all patients: five with isolated cirrhosis (two cryptogenic, one alcoholic, one hepatitis $\mathrm{C}$ virus, one steatohepatitis), one hepatitis $\mathrm{B}$ virus cirrhosis and another alcoholic, both associated with schistosomiasis, and other three had isolated schistosomiasis. Others illnesses were found, like type II diabetes (one patient), chronic colitis with sigmoid substenosis (two patients), chronic renal failure (one patient) and parkinsonism (one patient) (Table 2).

TABLE 2 - Associated diseases

\begin{tabular}{ll}
\hline Group I & \\
\hline Pat. & Associated diseases \\
1 & Cryptogenic cirrhosis + coronary disease + diabetes II \\
2 & Primary biliary cirrhosis \\
3 & Hypothyroidism \\
5 & Non-cirrhotic, antimitochondria $(>1 / 80)$ \\
7 & Hypothyroidism, arterial hypertension, chr. renal fail. \\
10 & Hypothyroidism + diabetes II, arterial hypertension, Raynaud \\
15 & Cryptogenic cirrhosis, antiparietal cell antibody $>1 / 320$ \\
18 & Non-cirrhotic, antiparietal cell antibody $>1 / 40$ \\
\hline & \\
\hline 4 & Froup II \\
6 & Vitty liver cirrhosis + diabetes II + colitis with sigmoid substenosis \\
8 & Cryptogenic cirrhosis + colitis with substenosis of descendent and sigmoid colon \\
9 & HS schistosomiasis + virus B cirrhosis + chr. renal fail. \\
11 & Cryptogenic cirrhosis \\
12 & HS schistosomiasis + alcoholic cirrhosis \\
13 & HS schistosomiasis \\
14 & Schistosomiasis \\
16 & Alcoholic cirrhosis \\
17 & Schistosomiasis \\
\hline
\end{tabular}

Fourteen patients were submitted to APC, with the number of sessions varying from 1 to 11 . Two of them were not followed, and other two died without completing the treatment. The 10 remaining patients were followed up for 2 to 36 months (average 9.9 months). Four patients had an excellent response to treatment, the lesions disappearing completely and showing increasing levels of hemoglobin. One of them is noteworthy because the vascular lesions disappeared after five sessions, without recurrence in 13 months after start of treatment. Thereafter follow-up was lost. One year later when the patient came back, the lesions had returned completely (Figure 2). Other three patients with an excellent response, lost followup too. Five patients showed short-term improvement in the endoscopic appearance and decrease in the number of blood

transfusions, however they developed fast recurrence of the lesions, requiring periodic sessions, every 3 months, but diminishing the need for blood transfusion. One of them died of sepsis from erysipela after 60 months of follow-up. Another patient developed hyperplastic gastric polyps after treatment with APC (Figure 3). One 1.5-cm polyp was resected, and the other, smaller than $0.7 \mathrm{~cm}$, were followed up (Table 3).

A patient who did not respond to the treatment with APC, died during an operation to control bleeding. This patient was treated for GAVE in another hospital, with laser. He had hemorrhagic recurrence 6 months later. Upper digestive endoscopy showed antral deformation and GAVE presence. APC treatment was started without hemorrhagic control, surgical treatment was then indicated. The stomach was seen to be attached to several structures during the surgery, leading to technical difficulties and bleeding.

One patient who was submitted to antral resection had an intense form of GAVE, widespread type, and received more than 100 units of red blood cells. APC was not available at the time.

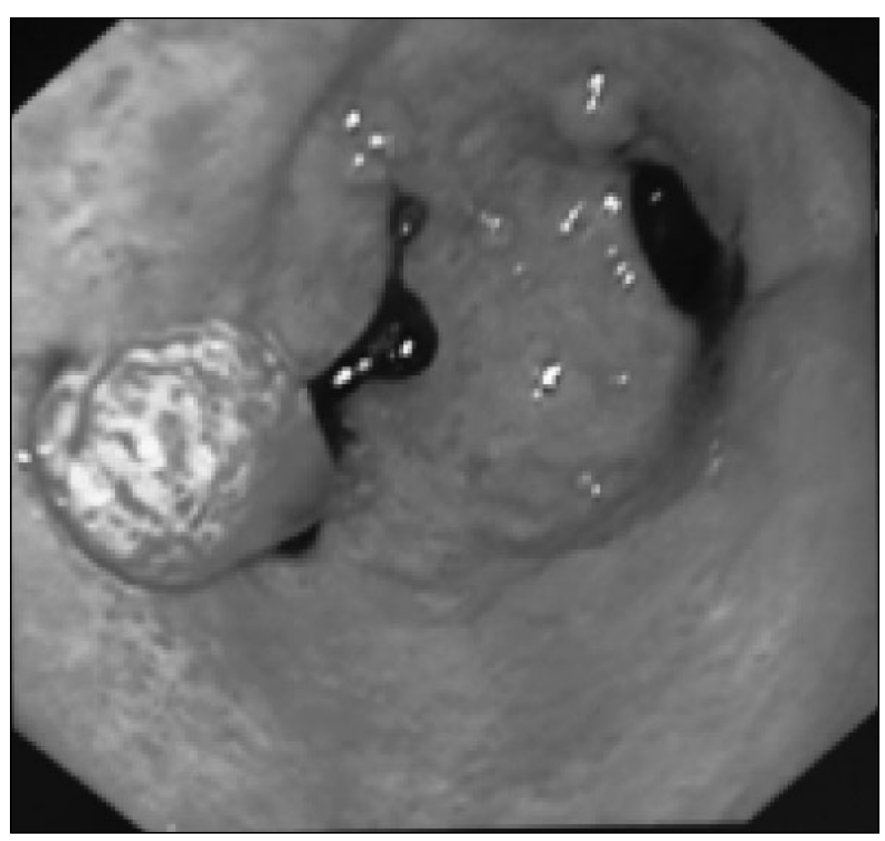

FIGURE 3 - Antral polyps, after APC sessions
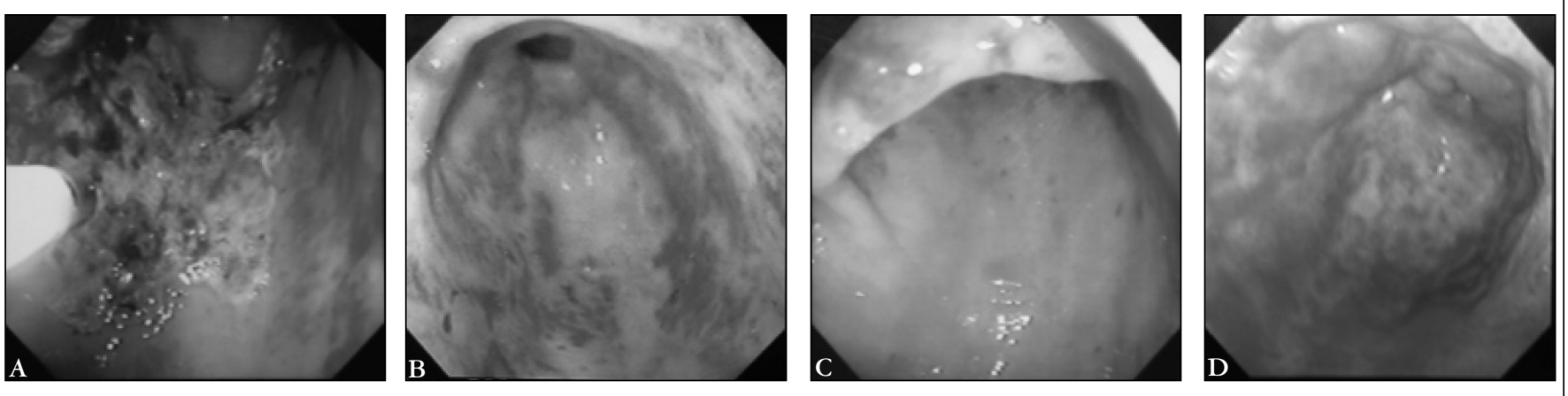

FIGURE 2 - Illustration of treatment with APC of a patient with diffuse GAVE: A-Immediately after APC application; B-Fifteen days after first session; C-Disappearance of vascular ectasia after 5 sessions of APC; D-Recurrence of vascular ectasia after 1 year of treatment 
TABLE 3 - Patients' evolution

\begin{tabular}{|c|c|c|c|c|}
\hline \multicolumn{5}{|l|}{ Group I } \\
\hline Patient & Treatment & Sessions & \multicolumn{2}{|r|}{ Follow-up (months) } \\
\hline 1 & Partial gastrectomy & - & 60 & Cure \\
\hline 2 & APC & 11 & 36 & Early recurrence, died of sepsis \\
\hline 3 & $\mathrm{APC}$ & 8 & 14 & Early recurrence \\
\hline 5 & $\mathrm{APC}$ & 5 & 13 & Excellent initial response \\
\hline 7 & APC & 2 & 1 & Controlled bleeding in an acute phase \\
\hline 10 & APC & 2 & 2 & Excellent initial response \\
\hline 15 & Not treated & - & - & - \\
\hline 18 & APC & 6 & 6 & Excellent initial response \\
\hline \multicolumn{5}{|c|}{ Group II } \\
\hline Patient & Treatment & Sessions & \multicolumn{2}{|r|}{ Follow-up (months) } \\
\hline 4 & Portocaval shunt + APC & 7 & 30 & Early recurrence Gastric polyps \\
\hline 6 & $\mathrm{APC}$ & 3 & 4 & Early recurrence \\
\hline 8 & Laser + APC & 1 & 12 & Bad. Death during surgery \\
\hline 9 & $\mathrm{APC}$ & 1 & 1 & No follow-up \\
\hline 11 & APC & 2 & 2 & Died without completing treatment \\
\hline 12 & APC & 1 & 1 & Died without completing treatment \\
\hline 13 & APDS 1998 & - & - & No follow-up \\
\hline 14 & APC & 2 & 3 & Recurrence \\
\hline 16 & Not treated & - & - & - \\
\hline 17 & $\mathrm{APC}$ & 3 & 4 & Excellent initial response \\
\hline
\end{tabular}

$\mathrm{APC}=$ argon plasma coagulation
$\mathrm{APDS}=$ azygoportal disconnection + splenectomy

\section{DISCUSSION}

GAVE is more common in females, specially when cirrhosis is excluded $^{(3)}$. Of our patients only one without cirrhosis was male. In the larger published series ( 45 patients), the age average was 73 years, with an approximate 3:1 predominance of the female gender $^{(7)}$. Frequently, GAVE is associated with chronic liver disease and autoimmune or connective tissue diseases, like primary biliary cirrhosis, hypothyroidism, progressive systemic sclerosis, Raynaud's phenomenon, sclerodactyly, atrophic body gastritis and pernicious anemia $^{(7)}$. Association with other diseases like coronary disease, chronic renal failure, diabetes, chronic obstructive pulmonary disease, parkinsonism ${ }^{(7)}$, lymphoma ${ }^{(16)}$, glucagonoma ${ }^{(23)}$ and bone marrow transplant ${ }^{(21)}$ were also reported.

Neuroendocrine tumor may develop in patients with watermelon stomach, generally in cases with atrophic gastritis. In this study there was one case of carcinoid tumor, with a 4.0 -cm diameter, excised by surgery during the antrectomy to treat the GAVE.

The clinical findings are chronic iron deficiency anemia and melena history, frequently requiring blood transfusions. Pernicious anemia due to atrophic gastritis is usually associated with iron deficiency anemia. In this series, as in other studies ${ }^{(12,13,16)}$, most patients had previously diagnosed severe enantematous gastritis. Low levels of serum iron, ferritin and hemoglobin below $9 \mathrm{~g} / \mathrm{dL}$ are the rule, affecting $87.5 \%$ of patients of this series. Prolonged prothrombin time is due to usually associated liver disease.

Endoscopically, two patterns of GAVE are usually recognized: the groovy (watermelon stomach) and the diffusely spread ${ }^{(13)}$. IKEDA et al. ${ }^{(8)}$ subdivided the diffuse pattern into spotty and confluent. ITO et al. ${ }^{(9)}$ call attention to the fact that all patients with a diffuse spotty pattern had cirrhosis, while all patients without cirrhosis had a groovy pattern ${ }^{(9)}$. We observed in this study that all 10 patients having the diffuse spotty type had liver disease with platelet levels below or equal to $90 \times 10^{3} / \mathrm{mm}^{3}$, and no patient with watermelon pattern, including those with cirrhosis, had platelets equal to or above $150 \times 10^{3} / \mathrm{mm}^{3}$. This relationship had not been described yet. We emphasize that the endoscopic findings in these patients was not compatible with congestive gastropathy or petechial bleeding.

On the other hand, we observed that the groovy pattern (watermelon) and the diffuse confluent type showed a strong association with autoimmune disease and atrophy of gastric mucosa. Three patients of this group had liver disease - one having primary biliary cirrhosis and two patients considered having cryptogenic cirrhosis, of whom one had antiparietal cell antibody and the other autoantibodies, were not investigated. In the five patients without liver disease, three had hypothyroidism, one had antimitochondria antibody $(>1 / 80)$ and other antiparietal cell antibody $>1 / 40$, though without cirrhosis.

The cause of GAVE remains unknown. Hypotheses of traumatic origin, as by mucosa prolapse through the pylorus ${ }^{(10)}$ and a humoral origin, involving locally released vasoactive substances ${ }^{(14)}$ were suggested. The lack of clinical or endoscopic improvement after performing a transjugular intrahepatic portocaval shunt (TIPS) or portal-systemic derivation surgery ${ }^{(11,19)}$ shows that portal hypertension is not the cause of GAVE, even in liver diseases. In this study, one patient underwent portocaval shunt and another azygoportal disconnection, both remained with GAVE. One patient that was submitted to liver transplant had upper digestive bleeding, secondary to GAVE 2 months after surgery.

Antral resection is the most effective form of treatment for these patients, but most of them are in no conditions for surgery, making the endoscopic treatment the first option. Only one patient of this study underwent a successful surgical antrectomy. Although, anemia improvement was achieved only after B12 vitamin was given.

Some studies showed improvement with the use of estrogenprogesterone in $\operatorname{GAVE}^{(4,15)}$ which might be the only treatment 
option in persistent cases without surgical condition and bad evolution on endoscopic treatment.

GAVE coagulation with Nd:YAG laser has shown high success rates regarding reduction or elimination of blood transfusions in most patients ${ }^{(22)}$. However the high cost of the equipment has restricted its availability. The only patient in our series that was submitted to laser treatment, had bleeding recurrence and scars that resulted in death during antrectomy. The description of gastric multifocal neoplasia after laser use for watermelon stomach is also a concern ${ }^{(2)}$.

APC brought a new hope for endoscopic treatment of these patients ${ }^{(1,5)}$. In an initial phase, all showed a reduction of vascular ectasia pattern as reported by PROBST et al. ${ }^{(17)}$. However, our study showed a higher recurrence incidence in the long-term, making repeated sessions necessary to control anemia. APC complications seem to be irrelevant

The development of hyperplastic polyps after laser treatment for watermelon was reported by GELLER et al. ${ }^{(6)}$ in 4 of $60(7 \%)$ patients. In our study it happened only in one patient, after four sessions of treatment.

Cessation of bleeding followed by endoscopic normalization 2 months after liver transplant was recently reported ${ }^{(19)}$. Although, the only case of our series submitted to liver transplantation had GAVE hemorrhagic recurrence.

We conclude by this study that GAVE has two different groups of patients with specific clinical and endoscopic findings. APC treatment showed a high recurrence incidence in the long-term, requiring repeated sessions for maintenance.

Chaves DM, Sakai P, Oliveira CV, Cheng S, Ishioka S. Ectasia vascular do antro gástrico ("watermelon stomach"): aspectos clínicos e tratamento com coagulação com plasma de argônio. Arq Gastroenterol. 2006;43(3):191-5.

RESUMO - Racional - "Watermelon stomach" ou ectasia vascular do antro gástrico é uma doença de etiopatogenia desconhecida. O tratamento endoscópico através da coagulação com plasma de argônio é considerado uma das melhores opções terapêuticas. Objetivo - Analisar os aspectos clínicos e endoscópicos da ectasia vascular do antro gástrico e a resposta ao tratamento com coagulação com plasma de argônio. Pacientes e métodos - Dezoito pacientes foram estudados e classificados em dois grupos: grupo I - oito pacientes que exibiam ectasia vascular do antro gástrico de aspecto difuso confluente ou estriado. Grupo II - 10 pacientes que apresentavam aspecto difuso pontilhado não-confluente. Resultados - Todos os pacientes do grupo I apresentavam auto-anticorpos, exceto um paciente no qual não foi pesquisado. Três eram cirróticos, três tinham hipotireoidismo e todos apresentavam gastrite atrófica. No grupo II, todos tinham doença hepática nãoautoimune, com plaquetas menores que 90.000. Dez pacientes foram submetidos a tratamento com coagulação com plasma de argônio, com 2 a 36 meses de seguimento. A ectasia vascular do antro gástrico recorreu em todos os pacientes que continuaram em acompanhamento e um paciente não respondeu ao tratamento para controle de sangramento agudo. Conclusão - Observou-se a existência de dois grupos distintos de pacientes com ectasia vascular do antro gástrico: um grupo associado a distúrbios imunológicos e outro com doença hepática não autoimune e plaquetopenia. $\mathrm{O}$ tratamento com coagulação com plasma de argônio apresentou alta recurrência das ectasias vasculares.

DESCRITORES - Ectasia vascular gástrica antral. Hemorragia gastrointestinal. Eletrocoagulação.

\section{REFERENCES}

1. Bernstein CN, Pettigrew N, Wang KK, Greenberg H, Lipschitz J. Multifocal gastric neoplasia after recurrent laser therapy for the watermelon stomach. Can J Gastroenterol. 1997;11:403-6.

2. Bourke MJ, Hope RL, Boyd P, Gillespie PE, Ward M, Cowen AE, Williams SJ. Endoscopic laser therapy for watermelon stomach. J Gastroenterol Hepatol. 1996;11:832-4

3. Cheung RC, Cooper S, Keefe EB. Endoscopic gastrointestinal manifestation of liver disease. Gastrointest Endosc Clin N Am. 2001;11:15-44.

4. Fischer NC, Pomiers-Layrargues G. Gastric antral vascular ectasia and its relation with portal hypertension. Gut 2000;46:441-2

5. Focke G, Seidl C, Grouuls V. Treatment of watermelon stomach (GAVE syndrome) with endoscopic argon plasma coagulation (APC). A new therapy approach. Leber Magen Darm. 1996;26:257-9.

6. Geller A, Gostout CJ, Balm RK. Development of hyperplastic polyps following laser therapy for watermelon stomach. Gastrointest Endosc. 1996;43:54-6.

7. Gostout CJ, Viggiano TR, Ahlquist DA, Wang KK, Larson MV, Balm R. The clinical and endoscopic of the watermelon stomach. Endoscopy 1992;15:256-63.

8. Ikeda M, Hayashi N, Imamura E, Kaneko A, Michida T, Yamamoto K, Kurosawa K, Kato M, Masuzawa M. Endoscopic follow-up study of development of gastric antra vascular ectasia associated with liver cirrhosis. J Gastroenterol. 1997;32:587-92.

9. Ito M, Uchida Y, Kamano S, Kawabata H, Nishioka M. Clinical comparisions between two subsets of gastric antral vascular ectasia. Gastrointest Endosc. 2001;53:764-70.

10. Jabbari M, Cherry R, Lough JO, Daly DS, Kinnear DG, Goresky CA. Gastric antral vascular ectasia: the watermelon stomach. Gastroenterology 1984;87:1165-70.

11. Kamath PS, Lacerda M, Ahlquist DA, McKusick MA, Andrews JC, Nagorney DA Gastric mucosal responses to intrahepatic portosystemic shunting in patients with cirrhosis. Gastroenterology 2000;118:905-11.

12. Kruger R, Michael ER, Kenneth BD, Nunez JF. Diffuse vascular ectasia of the gastric antrum. Am J Gastroenterol. 1987;82:421-6.

13. Lee FI, Costello F, Flanagan N, Vasudev KS. Diffuse antral vascular ecasia. Gastrointest Endosc. 1984;30:87-90
14. Lowes JR, Rode J. Neuroendocrine cell proliferations in gastric antral vascular ectasia. Gastroenterology. 1989;97:207-12

15. Moss SF, Ghosh P, Thomas DM, Jackson JE, Calam J. Gastric antral vascular ectasia: maintenance treatment with oestrogen-progesterone. Gut. 1992;33:715-7.

16. Park RHR, Danesh BJZ, Upadhyay R, Howatson AG, Lee FD, Russel RI. Gastric antral vascular ectasia (watermelon stomach) - therapeutic options. Postgrad Med J. 1990;66:720-3.

17. Probst A, Scheubel R, Wienbeck M. Treatment of watermelon stomach (GAVE syndrome) by means of endoscopic argon plasma coagulation (APC): long term outcome. Z Gastroenterol. 2001;39:447-52

18. Rider JA, Klotz AP, Kirsner JB. Gastritis with veno-capillary ectasia as a source of massive gastric hemorrhage. Gastroenterology. 1953;24:118-23.

19. Spahr L, Villeneuve JP, Dufresne MP, Tassé D, Bui B, Willems B, Fenyves D, PomiersLayrargues G. Gastric antral vascular ectasia in cirrhotic patients: absence of relation with portal hypertension. Gut. 1999;44:739-42.

20. Suit PF, Petras RE, Bauer TW, Petrini JL. Gastric antral vascular ectasia. A histologic and morphometric study of "the watermelon stomach". Am J Surg Pathol. 1987;11:750-7.

21. Tobin RW, Hackman RC, Kimmey MB, Durtschi MB, Hayashi A, Malik R, McDonald MF, McDonald GB. Bleeding from gastric antral vascular ectasia in marrow transplant patients. Gastrointest Endosc. 1996;44:223-9.

22. Tran A, Villeneuve JP, Bilodeau M, Willems M, Marleau D, Fenyves D, Parent R, Pomiers-Layrargues G. Treatment of chronic bleeding from gastric antral vascular ectasia (GAVE) with estrogen-progesterone in cirrhotic patients: an open pilot study. Am J Gastroenterol. 1999;94:2909-11.

23. Weitgasser R, Sungler P, Hauser-Kroberger C, Dietze O, Sattlegger P, Hacker GW. Immunohistochemical assessment of an asymptomatic glucagonoma in a patient with hypergastrinemia and marked antral angiodysplasia. Appl Immunohistochem Molecul Morphol. 2001;9:92-6.

Recebido em 6/5/2005. Aprovado em 26/1/2006. 